\title{
Brand Registration in The Perspective of The Culinary Industry in Bogor City and Bogor Regency A Legal Approach
}

\author{
Suherdiman ${ }^{1}$, Riswadi $^{2}$ \\ $\left\{\right.$ Suherdiman.sh.mkn@gmail.com ${ }^{1}$, riswadi@borobudur.ac.id $\left.{ }^{2}\right\}$ \\ Universitas Borobudur, Faculty Of Law, Jakarta, Indonesia ${ }^{1,2}$
}

\begin{abstract}
As follows: 1) Brand is one of the essential attributes of a product, where the brand of a product can provide added value for the product. A brand is not only a name for a product but more than an identity to distinguish it from effects produced by other companies., 2) Now, the public in submitting applications is no longer experiencing difficulties because the Government, through the Directorate General of Intellectual Property Rights, has done a lot of socialization through mass media and forums that have been established. 3) the protection of trademark rights owners who have gone through several stages of the selection process for trademark registration. This is proven by several laws and government regulations of the Republic of Indonesia, which are continually updated along with the development and increasing competition. In the world of trade, both nationally and internationally. As a result of the existence of these legislation, different types of offenses in the sphere of Patentability, particularly trademarks, can be suppressed.
\end{abstract}

Keywords: Registration; Brand; Culinary Industry; Legal Approach

\section{Introduction}

The brand is one of the essential attributes of a product, where a brand can give extra value to the product. The brand is not just a name for products, but more than that is an identity to distinguish from products products products.[1] With a unique identity, a particular product would be easier to recognize by the consumer and, in turn, would undoubtedly be more accessible when purchasing the product. The brand comprises two parts that brands can pronounce and recognize but not be branded.[2]

Now the public in making applications have not been having any trouble since the Government has been through DITJEN HKI have many socializing through mass media nor the forum that has been formed so that the ultimate rights owner should not worry about the loss caused by an irresponsible person who wants to use the popularity of a particular product.

That we've discussed the previous page of protection against the owner of the brand-rights process has been very strict with several stages of the registration process of the registration of the Indonesian Republic government regulations and the more the outrageous competition in the world of trade and international trading.[3] So that with some of those regulations can press various crimes in particular brands of wealth. 


\section{Method}

This study uses a normative methodology, The data used in this research is secondary data derived from normative data. On the other hand, the descriptive-analytical approach is a method that uses data or samples gathered as-is to describe or present an overview of the topic under investigation without analyzing or drawing conclusions that apply to the general public. In other words, when conducting research, analytical descriptive research considers difficulties or focuses emphasis on topics. The study's findings are subsequently processed and examined to get a conclusion. The author employs the descriptive analysis approach since it is appropriate for understanding the present phenomena.

\section{Discussion}

\subsection{Brand Dispute Resolution in Brand Protection}

Copyright, according to Law Number 28 of 2014, is an individual right arising from the declarative principle of invention manifested in a concrete form without the need of laws and regulations to reduce synchronous limits. Human-value-based activities with specific exclusive economic rights since the right is only granted to a person or group of persons who have created a work, such as a trademark.

A pattern is a symbol in the form of an image, name, word, letter, number, color arrangement, or a combination of these components that has distinguishing power and is used in commerce and services, according to article 1 number 1 of Law 20 of 2016 governing marks and geographical indications. Trademarks must be registered in order to gain legal protection from others using similar marks. Furthermore, this regulation is governed by Article 4 paragraph 1 number 20 of 2016 respecting Marks and Geographical Indications in order to achieve legal legality.

Dispute resolution in the litigation pathway is a type of dispute resolution that takes place in court between two parties. This issue is addressed under the auspices of the judiciary and requires the submission of evidence in order to avoid future conflicts. This is governed by Article 22 of the 1945 Constitution, which provides that the Supreme Court has ultimate authority over the judicial system and that the court is the last arbiter of disputes. The ruling results include regulations that the disputing parties must follow.

The exclusive right granted by the state to the owner of a Mark registered in the general register of marks is known as protection of a mark or right to a mark. For a limited time, he utilizes the Mark himself, or he allows a group of individuals or a legal entity to use it. The availability of legal clarity about Registered Marks, including whether they can be used, extended, transferred, or deleted as evidence in the event of a Registered Mark infringement dispute.

A brand is a distinctive sign of goods or services for one company to another or individual owners from one another. As a distinguishing mark, a mark in one qualification of goods/services may not have similarities, both in whole and in essence. The definition of equality in its entirety is if it has similarities in terms of origin, nature, method of manufacture and purpose of use. The basic understanding of the equation is if it has parallels in form 
equations, similarities in placement methods, equations in form and placement methods, similarities in speech sounds.

Marks used or affixed to goods traded by a person or persons or legal entities are generally referred to as trademarks on goods. A name, word, image, letter, number, color arrangement, or a combination of these elements can be used as a distinguishing mark.

\subsection{The Urgency of Legal Protection for MSME Industrial Brands in Indonesia}

The importance of trademark protection cannot be overstated. Trademarks serve as identification marks for goods and services, indicating their origin and connecting the items and services to their makers.[4] Apart from being a property that can generate profits for entrepreneurs as brand owners, it is also a tool to protect the public as consumers from fraud on the quality of certain goods. Consumers will be dissatisfied if the brand they believe is of great quality is really created by a low-grade third party. When goods and services are traded, brands describe the guarantee of personality (individuality) and the reputation of business success. Quality assurance of a product or service is beneficial for producers in business competition and at the same time provides product guarantee protection to consumers.

According to the Director-General of Intellectual Property Rights, the use of a Mark serves as an identification mark to distinguish the production results produced by a person or several persons or a legal entity from the production results produced by another person or other legal entity, then as a promotional tool so that simply mentioning the Mark is enough to promote the products produced, as a guarantee for the quality of the goods, and as an indication of the goods' origin.

Due to the reasons above, legal protection of marks is significant. Other parties do not use them against the law, such as counterfeiting and imitation, creating unfair trade competition and ultimately harming the brand owner. To obtain legal protection for the Mark, the Mark must be registered first. The Director-General of Intellectual Property Rights stated that the registration of a mark serves as evidence for the owner who is entitled to a registered mark, as a basis for rejection of a Mark which is the same in its entirety or the same in principle for which another person applies for registration for goods or services of the same type, and also serves as a basis for preventing other people use the same Mark wholly or essentially the same in circulation for goods or services of the same kind.

Business actors have not fully realized the importance of trademark registration in Indonesia. In Indonesia, there are classes of business actors such as Micro, Small and Medium Enterprises (MSMEs), which in percentage terms are still few who have registered their trademarks with the Director-General of IP compared to non-MSME business actors.[5] As the data described previously, namely the statistical data on the Directorate General of Information and Communication Technology registration, shows that during the 2016-April 2018 period, registration of Non-MSME Marks dominated 91.45\%, while for MSME brands, it was only $8.55 \%$. MSME business actors are different from Non-MSME business actors, which can be seen from the scale of capital, assets and annual profits obtained. MSMEs are under the auspices of the Ministry of Cooperatives and Small and Medium Enterprises of the Republic of Indonesia. The definition and criteria for MSMEs under Law Number 20 of 2008 concerning Micro, Small, and Medium Enterprises are a) micro-enterprises, b) small-scale enterprises, and medium-sized enterprises.

Based on the function of trademark registration as described in particular for MSME brands, and due to the emergence of MSME brand protection by way of trademark registration, It will encourage workers to work harder and have a good impact on enhancing 
competitiveness, hence raising the revenue of MSME business owners. As a result, efforts must be made to enhance the percentage of MSME industrial marks that are registered.[6]

In Indonesia, the Trademark Law No. 20 of 2016 governing Brands and Geographical Indications does not cover much in terms of MSME Brands. The phrase "that in the era of global commerce, in line with international treaties that Indonesia has ratified, the function of Marks and Geographical Indications is vital, especially in preserving fair and just economic competition" appears in the preamble to letter an of the 2016 Trademark Law. Consumer protection as well as protection for home industries and Micro, Small, and Medium Enterprises.

Based on these factors, it is clear that the 2016 Trademark Law's primary goal is to give legal clarity and protection, particularly to domestic consumers and business actors, as well as to promote healthy economic competition. Healthy business competition, on the other hand, can only exist if major industries do not use their dominating position to repress the MSME sector. Nonetheless, they must work together to administer an economy without monopolizing it.

The presence of the 2016 Trademark Law is intended to be one way for the government to assist MSME enterprises by allowing trademarks to protect their intellectual property. Because the government recognizes and protects the ownership of a registered Mark issued to MSME business actors, major industries or business players with unscrupulous motives cannot automatically seize intellectual property belonging to MSME company actors. Assume a disagreement emerges as a result of a trademark ownership issue.In that case, the Government will only refer to the Mark certificate as proof of ownership of the right to the Mark,20 unless there is a cancellation of the right to the Mark based on a trademark lawsuit made by one of the parties in the Commercial Court. MSME industry brands in Indonesia are carried out by increasing the MSME industry to register trademarks by MSME actors. The MSME industry will only get legal protection of the Mark if it has registered its Mark.

\section{Conclusion}

Based on the description above, it can be concluded that the effort to provide brand protection to the MSME industry is by registering the MSME brand. Thus, because the criteria for MSME industry business actors have limitations in terms of capital, assets and annual sales results compared to Non-UMKM business actors, the Government makes it easy for MSME industry players to register brands, namely through a lower MSME brand registration fee policy. Cheap compared to non-UMKM brands, cooperate with the Director-General of Intellectual Property of the Ministry of Law and Human Rights and the Ministry of Cooperatives and MSMEs, provide financial incentives for registration of MSME brand registrations, as well as registration of collective marks for the MSME industry.

\section{References}

[1] B. N. Iskandar, "Kedudukan Akta Notaris Dalam Penyelesaian Sengketa Penghapusan Merek Di Luar Pengadilan," Notary J., vol. 1, no. 1, pp. 49-68, 2021.

[2] S. Agarwal, N; Dokoohaki, N; Tokdemir, Emerging research challenges and opportunities in computational social network analysis and mining. 2019.

[3] J. Liu, S. Jou, and B. Hebenton, Handbook of Asian: Finance, vol. 2. 2014. 
[4] L. Mariana, M. Rachmawati, E. E. Supriyanto, F. J. Nugroho, and D. M. Sanusi, "Peningkatan Produktivitas dan Profitablitas UMKM Desa Sampulungan Kabupaten Takalar Sulawesi Selatan,” J. Train. Community Serv. Adpertisi, vol. 1, no. 1, pp. 1-15, 2020.

[5] L. Nugroho, A. A. Mastur, H. Harnovinsah, and W. Aryanti, "The Contribution of Islamic Bank in Poverty Alleviation,” Al-Ahkam, vol. 30, no. 1, p. 19, 2020, doi: 10.21580/ahkam.2020.30.1.5387.

[6] M. Kurdi, D. Kurniawati, V. Andrianingsih, A. Furqani, N. Alfiyah, and M. Arifin, "The Government's Role in MSMEs Development Through E-Commerce in Sumenep Regency," 2021, doi: 10.4108/eai.6-3-2021.2306388. 